\title{
Swine flu panic
}

Ever since international public health authorities decided that a small outbreak of flu in Mexico offered a good opportunity to test drive their recently-prepared pandemic flu contingency plans, our local PCT has plunged enthusiastically into scare-mongering mode. ${ }^{1}$ Daily meetings of senior staff have rubber-stamped national policy, dutifully passing on algorithms and instructions (up to three times a day) from the Health Protection Agency and other bodies to local surgeries and pharmacies and generally promoting public anxieties about impending viral Armageddon.

Of course, there is nothing new in local health authorities meekly complying with directives (however absurd) from on high, whether from the government or the World Health Organization (an even more remote bureaucracy). But the scale of irrationality of the swine flu scare exceeds that of any earlier panic. As news media (and the PCT) gleefully reported on the steadily rising level of pandemic status, one commentator described the process as 'global public health meets This Is Spinal Tap, and this panic is being turned all the way up to $11 .{ }^{\prime 2}$

How many people in Hackney have been afflicted with swine flu? Well, at the time of writing, none (no doubt this will be subsequently claimed as proof of the effectiveness of the policy). Indeed, there have only been a handful of cases in the whole country and these appear to have suffered little worse than a mild cold. Yet eminent public health authorities and virologists continue to issue apocalyptic warnings: current cases may be mild, but the virus might mutate and become more virulent and more infectious; it might become resistant to drugs or immune to immunisations; it might kill 20 million people (like the Spanish flu of 1918-1919), or indeed it might wipe out the whole of humanity. Or maybe not.

As a veteran of earlier epidemics which experts predicted would decimate the population of the UK, I am sceptical about doomsday scenarios - and increasingly despairing at the corruption of science by propaganda in the sphere of public health. This all started with AIDS in the late 1980s and continued with the BSE/CJD scare in the late 1990s. Then we had SARS in 2003 and, most recently, avian flu in 2005, which leading WHO authorities speculated might kill between 5 and 150 million people ${ }^{3}$ (the final global death toll was 216). It is striking that while the scale of public anxiety has steadily increased in response to these scares, the number of fatalities has declined. Public health zealots are increasingly resorting to the rhetoric of tombstones and icebergs - and pandemics - in relation to obesity.

Promoters of these health scares combine grim warnings of the threat of mass mortality with bland exhortations that there is no need to panic (nothing could be less reassuring). They commonly appeal for vigilance and issue banal advice, such as that circulated by the government to every household in the country about swine flu (and dutifully circulated to GPs by the PCT). It seems doubtful that the suggestion that used tissues should be disposed of in a bin will make a major contribution to stopping the spread of the flu virus, ${ }^{4}$ although it may deter some people from keeping them in the fridge.

Of course, it is easy to ignore the increasingly absurd flu alerts from the PCT and other agencies. But while those running primary care services are preoccupied with non-existent diseases, doctors and nurses in surgeries are struggling with a mounting workload of people with real health problems (as well as a few with media-generated anxieties). As Simon Jenkins commented on the first case of swine flu in London, 'Nothing justified the pandemonium with which the British authorities and media greeted news of the illness last week'.5

\section{REFERENCES}

1. Fitzpatrick M. Pandemic plague contingency plan. Br J Gen Pract 2007; 57(534): 77. http://www.pubmedcentral.nih.gov/articlerender.f cgi?artid=2032711 (accessed 18 May 2009).

2. Lyons R. Swine flu: official panic is making things worse. Spiked Online, 30 April, 2009. http://www.spiked-

online.com/index.php?/site/article/6620/ (accessed 7 May 2009).

3. 'Bird flu 'could kill $150 \mathrm{~m}$ people'. BBC online, 30 September, 2005

http://news.bbc.co.uk/1/hi/world/asiapacific/4292426.stm (accessed 7 May 2009)

4. Swine flu - prevention and treatment. DirectGov, 4 May, 2009.

http://www.direct.gov.uk/en/Swineflu/DG_1778 4 (accessed 7 May 2009).

5. Jenkins $\mathrm{S}$. There is no known antidote for panic The Guardian 2009; 5 May.

http://www.guardian.co.uk/commentisfree/2009/ may/05/swine-flu-panic (accessed 7 May 2009). 